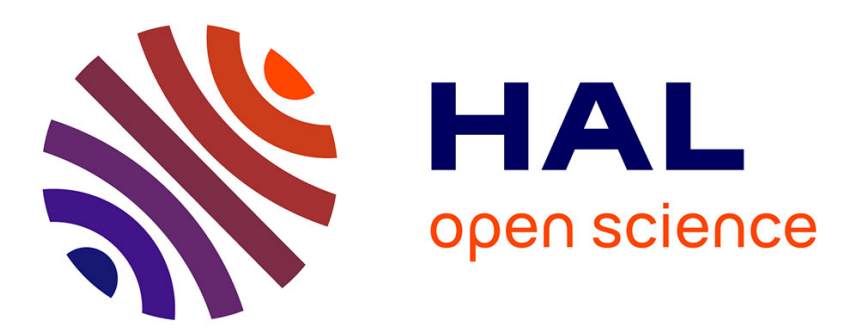

\title{
The atmospheric concentration of sulfure dioxide and sulfate aerosols over antarctic, subantarctic areas and oceans
}

Ba Cuong Nguyen, Bernard Bonsang, Gérard Lambert, Nguyen Ba Cuong

\section{- To cite this version:}

Ba Cuong Nguyen, Bernard Bonsang, Gérard Lambert, Nguyen Ba Cuong. The atmospheric concentration of sulfure dioxide and sulfate aerosols over antarctic, subantarctic areas and oceans. Tellus A, 1974, 26 (1-2), pp.241 - 249. 10.3402/tellusa.v26i1-2.9783 . hal-03407002

\section{HAL Id: hal-03407002 \\ https://hal.science/hal-03407002}

Submitted on 28 Oct 2021

HAL is a multi-disciplinary open access archive for the deposit and dissemination of scientific research documents, whether they are published or not. The documents may come from teaching and research institutions in France or abroad, or from public or private research centers.
L'archive ouverte pluridisciplinaire HAL, est destinée au dépôt et à la diffusion de documents scientifiques de niveau recherche, publiés ou non, émanant des établissements d'enseignement et de recherche français ou étrangers, des laboratoires publics ou privés. 


\section{Tellus}

\section{The atmospheric concentration of sulfure dioxide and sulfate aerosols over antarctic, subantarctic areas and oceans}

\section{Nguyen Ba Cuong, Bernard Bonsang \& Gérard Lambert}

To cite this article: Nguyen Ba Cuong, Bernard Bonsang \& Gérard Lambert (1974) The atmospheric concentration of sulfure dioxide and sulfate aerosols over antarctic, subantarctic areas and oceans, Tellus, 26:1-2, 241-249, DOI: 10.3402/tellusa.v26i1-2.9783

To link to this article: https://doi.org/10.3402/tellusa.v26i1-2.9783

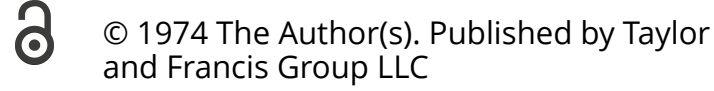

曲 Published online: 15 Dec 2016.

Submit your article to this journal $₫$

Џll Article views: 155

Q View related articles $₫$ 


\title{
The atmospheric concentration of sulfure dioxide and sulfate aerosols over antarctic, subantarctic areas and oceans
}

\author{
By NGUYEN BA CUONG, BERNARD BONSANG and GÉRARD LAMBERT, ${ }^{1}$ \\ Centre des Faibles Radioactivités, Laboratoire mixte CNRS/CEA, 91190-Gif-Sur-Yvette, France
}

(Manuscript received May 21; revised version November 13, 1973)

\begin{abstract}
During several trips, measurements of sulfur dioxide and sulfate aerosols have been taken over Antarctic and Subantarctic areas and also over the Mediterranean Sea. A special application of the West Gaeke method enabled us to measure $\mathrm{SO}_{2}$ concentrations in Antarctic and Subantaretic areas, ranging from 0.05 to $1 \mu \mathrm{g} / \mathrm{m}^{3}$. $\mathrm{SO}_{2}$ and sulfate aerosols concentrations in these areas are then compared with concentrations observed in other areas.
\end{abstract}

\section{Introduction}

Measurements of sulfur compounds have been taken mainly in industrial areas. Few of them have been performed far from urban zones, such as in oceanic regions, and even fewer over Antarctic and Subantarctic areas.

Nevertheless, oceans produce $\mathrm{SO}_{4}^{-}$by the bursting of myriads of sea water bubbles containing about $2.65 \mathrm{mg}$ of $\mathrm{SO}_{4}^{-=}$per gram of $\mathrm{H}_{2} \mathrm{O}$ (Kellogg et al., 1972), and because of their large surface, oceans could also produce a non-negligible quantity of $\mathrm{SO}_{2}$ and $\mathrm{SO}_{4}^{-}$by oxidization of $\mathrm{H}_{2} \mathrm{~S}\left(202.10^{6}\right.$ tons/year of $\mathrm{H}_{2} \mathrm{~S}$ oceanic after Eriksson, $(1959,1960)$ but only $30.10^{6}$ tons after Robinson \& Robbins (1969)). Eriksson $(1959,1960)$ estimates the annual production of $\mathrm{SO}_{4}^{-}$by sea water bubbles at $130.10^{6}$ tons, $10 \%$ of which passes over the continents. Recently, Lovelock et al. (1972) suggested that dimethyl sulfide (DMS) was the natural sulfur compound which played the role previously attributed to $\mathrm{H}_{2} \mathrm{~S}$. According to Challenger (1951), DMS is produced by many living systems, especially marine algae.

Kellogg et al. (1972) believe that "Man is now contributing about one-half as much as nature to the total atmospheric burden of sulfur compounds". Likewise Friend (1973) found a

1 Université de Picardie. contribution to the atmosphere of 65 tons/year of pollution $\mathrm{SO}_{2}$ and of 108 tons/year of biogenic sulfur (gaseous) and volcanic $\mathrm{SO}_{2}$.

In order to contribute to the determination of a natural product budget of these compounds, we decided to investigate a region where $\mathrm{SO}_{2}$ and sulfate aerosol sources of non-oceanic origin would be minimal. Therefore, it was obvious to study the Antarctic and the Subantarctic regions which are entirely covered with ice or sea water. Thus, since 1971 we have made measurements of atmospheric $\mathrm{SO}_{2}$ and sulfate aerosol concentrations on board oceanographic ships during Antarctic and Subantaretic expeditions.

\section{2. $\mathrm{SO}_{2}$ measurements}

The main difficulty in these areas is due to very low $\mathrm{SO}_{2}$ atmospheric concentrations which have been only measured by Cadle et al. (1968) and proved to be smaller than $\mathrm{I}$ to $3 \mu \mathrm{g} / \mathrm{m}^{3}$. It was therefore necessary to build an apparatus sensitive enough to measure $\mathrm{SO}_{2}$ atmospheric concentrations of at least $0.05 \mu \mathrm{g} / \mathrm{m}^{3}$ for a reasonable sampling time. The use of the West Gaeke method (1956) with some care in air sampling and of a spectrophotometer of high performance (such as in our experiments: Zeiss PMQ II) made possible the measurements of

Tellus XXVI (1974), 1-2

$16-742891$ 


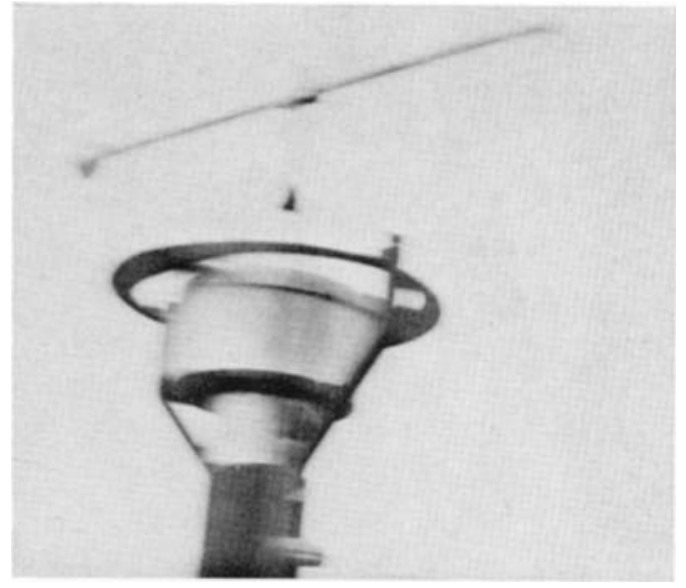

Fig. 1. System to avoid $\mathrm{SO}_{2}$ sampling from contaminations by ship exhausts.

such low concentrations. Since this spectrometer is a laboratory fixture, the operations therefore consist of three distinct phases: sampling, sample storage and analysis.

\section{Sampling}

The most important thing for atmospheric $\mathrm{SO}_{2}$ sampling on board, is to exclude from these samples any smoke from the ship. For this reason, the air inlet of the $\mathrm{SO}_{2}$ sampling device is always placed on the forecastle. We designed a system to cut off automatically the power of the $\mathrm{SO}_{2}$ device as soon as the wind blows from astern (Fig. 1). An electrical control connects this system with the $\mathrm{SO}_{2}$ sampling device (Fig. 2). To obtain a sufficient amount of $\mathrm{SO}_{2}$, each sampling is made during 24 hours with an air flow of 3 litres per minute. The air flows through a Millipore filter and then through a $10 \mathrm{~cm}^{3}$ solution of sodium tetrachloromercurate, thus forming a dichlorosulfitomercurate(II) complex. The long duration of the sampling requires the use of an electromagnetic device for automatic volume control of the solution (Fig. 3).

\section{Storage}

As we could not have a sufficiently sensitive spectrophotometer on board the ship, we had

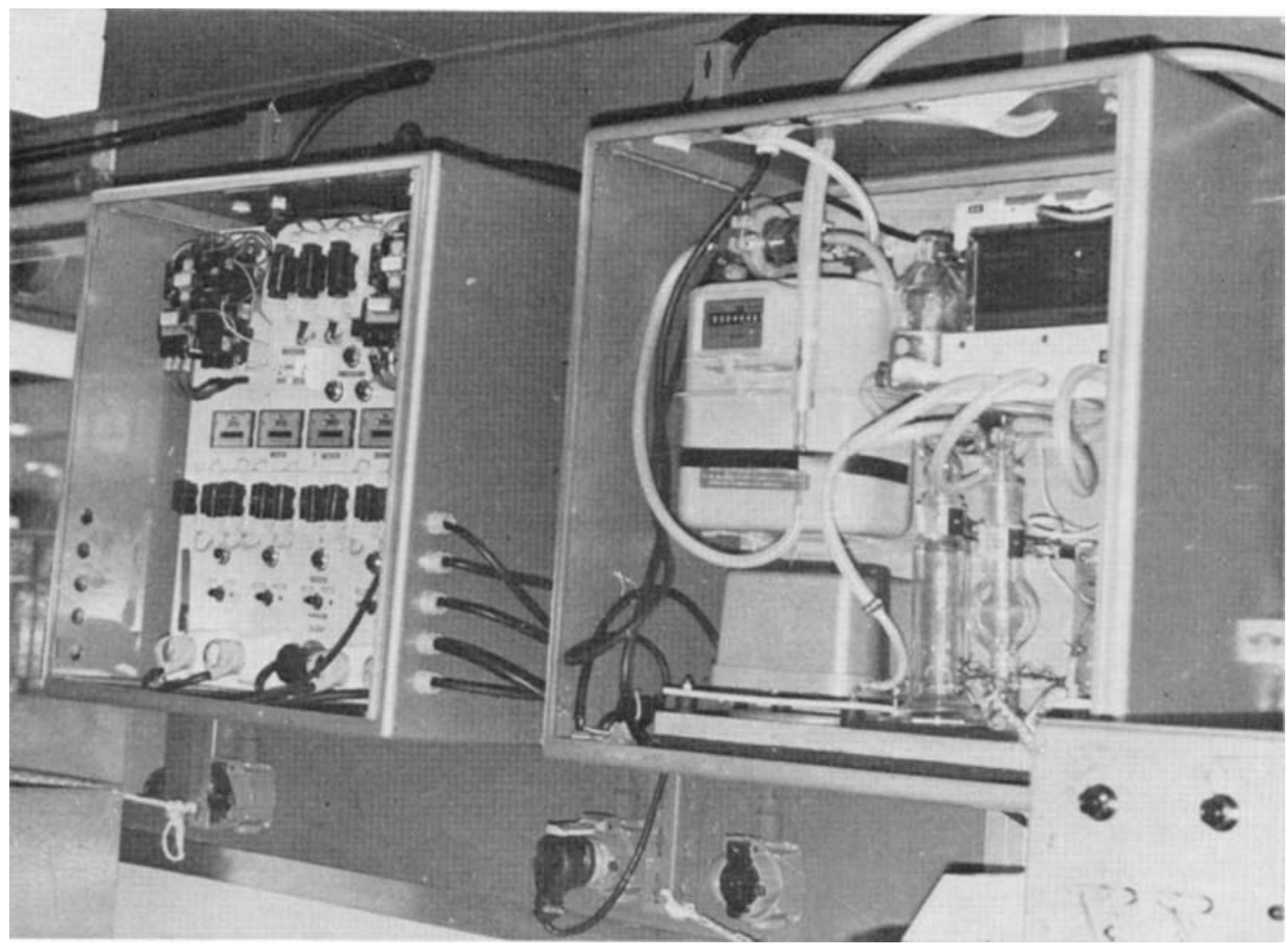

Fig. 2. Electrical control (on the left) and $\mathrm{SO}_{2}$ sampling device (on the right). 


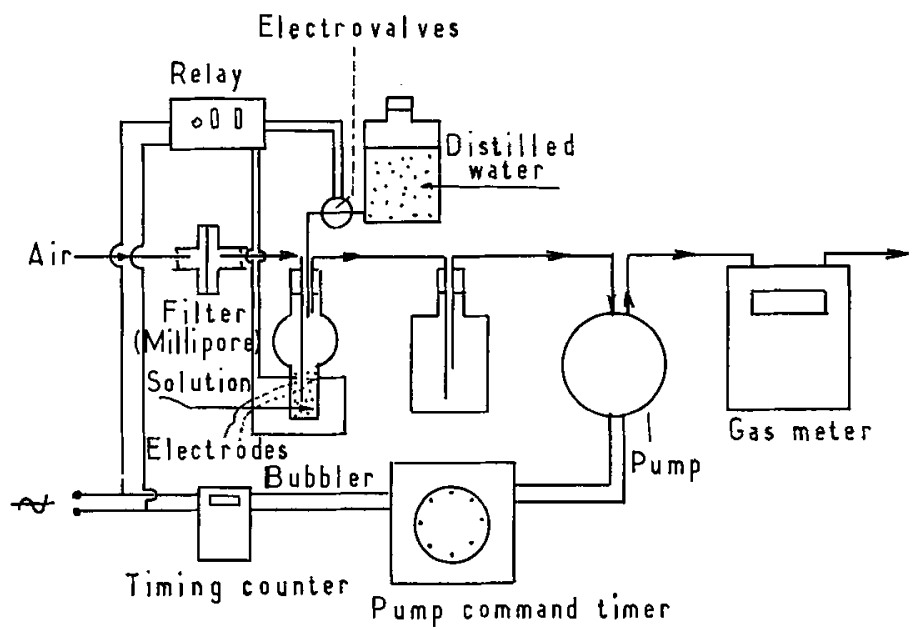

Fig. 3. Schema of $\mathrm{SO}_{2}$ sampling device.

to store our samples on board before being analysed in the laboratory about one month later. Unfortunately the dichlorosulfitomercurate complex is not very stable. The solution must therefore be kept at the temperature for which the stability is optimum. Lahmann (1969) found that stability is better at $5^{\circ} \mathrm{C}$ than at higher temperatures. After several laboratory experiments between $+20^{\circ} \mathrm{C}$ and $-25^{\circ} \mathrm{C}$, we established that the optimum temperature is about $0^{\circ} \mathrm{C}$.

The stability of this complex solution also increases with concentration. Finally, for quantities of $\mathrm{SO}_{2}$ in the range of 0.2 to $3 \mu \mathrm{g}$ in 10 $\mathrm{cm}^{3}$ of absorbent solution, the losses are be-

Table 1. Stability $(\%)^{a}$ of dichlorosulfitomercurate solution after one or four weeks at various temperatures

\begin{tabular}{|c|c|c|c|c|}
\hline \multirow{2}{*}{$\begin{array}{l}\text { Tempera- } \\
\text { ture of } \\
\text { storage } \\
\left({ }^{\circ} \mathrm{C}\right)\end{array}$} & \multicolumn{2}{|c|}{$\begin{array}{l}\mathrm{SO}_{2} \text { concentra- } \\
\text { tion of } 0.2 \text { to } \\
0.5 \mu \mathrm{g} / 10 \mathrm{~cm}^{3} \\
\text { absorbent solution }\end{array}$} & \multicolumn{2}{|c|}{$\begin{array}{l}\mathrm{SO}_{2} \text { concentra- } \\
\text { tion of } 1.0 \text { to } \\
3.0 \mu \mathrm{g} / 10 \mathrm{~cm}^{3} \\
\text { absorbont solution }\end{array}$} \\
\hline & $\begin{array}{l}\text { After } \\
\text { I week }\end{array}$ & $\begin{array}{l}\text { After } \\
4 \text { weeks }\end{array}$ & $\begin{array}{l}\text { After } \\
\text { l week }\end{array}$ & $\begin{array}{l}\text { After } \\
4 \text { weeks }\end{array}$ \\
\hline+20 & 78.0 & 65.0 & 84.5 & 72.5 \\
\hline+2 & 87.5 & 69.0 & 90.0 & 85.5 \\
\hline-15 & 81.0 & 69.5 & 76.0 & 74.0 \\
\hline-25 & 84.0 & 67.5 & 76.0 & 75.0 \\
\hline
\end{tabular}

$a$ Reference $=100 \%$ for a measurement immediately after preparation of solution. tween 31 and $14.5 \%$ after 4 weeks at $2{ }^{\circ} \mathrm{C}$ (see Table 1). Experimental details will be published later.

\section{Analysis and possible interferences}

Traces of heavy metals ( $\mathrm{Fe}, \mathrm{Mn}$ ) catalyse the $\mathrm{SO}_{2}$ oxidization in the solution. We have eliminated this interference by adding to the absorbent solution a chelating agent (EDTA, 0.05 $\mu \mathrm{g} / 10 \mathrm{~cm}^{3}$ ) (Zurlo \& Griffini, 1962).

Interference from nitrogen dioxide is also eliminated by adding sulfamic acid (Pate et al., 1965).

Oxidization of $\mathrm{SO}_{2}$ by $\mathrm{O}_{3}$ in the absorbent solution has not yet been measured. However, recent results show that the oxidization rate of $\mathrm{SO}_{2}$ in solution is $12.6 \%$ per hour for $\mathrm{pH}$ and concentration conditions (Penkett, 1972) are very similar to those encountered here. A much smaller figure was found by us for atmospheric samples. This may be explained by the following fact: the $\mathrm{O}_{3}$ molecules are much more likely to be destroyed by the reagents present in the absorbent solution in ponderable concentration than by the $\mathrm{SO}_{2}$ traces.

The complex formed in the absorbent solution reacts with formaldehyde and pararosaniline in acid solution to form a pararosaniline methylsulfonic acid. The intensity of the color of this compound is measured spectrophotometrically at $560 \mathrm{~m} \mu$.

With our spectrophotometer we can measure, for instance, with a possible error of $2 \%$, a

Tellus XXVI (1974), 1-2 


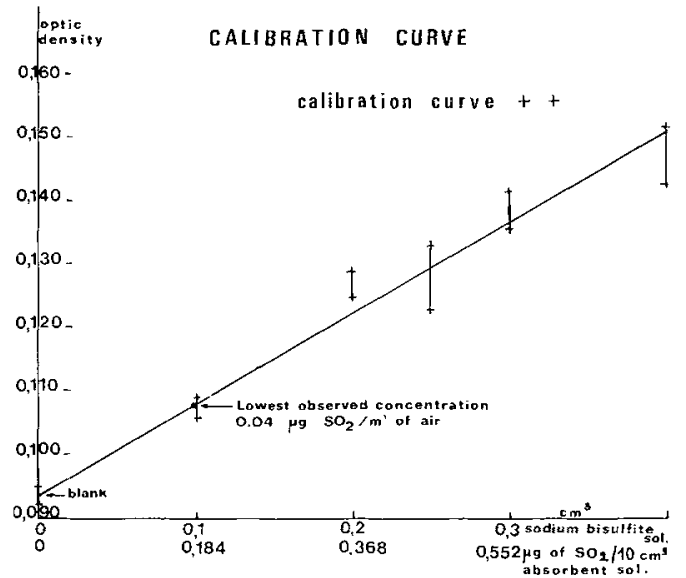

Fig. 4. Calibration curve.

concentration of $0.02 \mu \mathrm{g} \mathrm{SO}_{2}$ per $\mathrm{cm}^{3}$ of absorbent solution, corresponding to $5 \mathrm{~m}^{3}$ of air with $0.04 \mu \mathrm{g} \mathrm{SO}$ per $\mathrm{m}^{3}$. Fig. 4 shows one of our calibration curves where the lowest concentration observed in this work is indicated $(0.04$ $\left.\mu \mathrm{g} / \mathrm{m}^{3}\right)$. The optic density corresponding to this concentration is obviously higher than the blank ones.

\section{$\mathrm{SO}_{2}$ results}

$\mathrm{SO}_{2}$ atmospheric concentrations measured in the present work are shown in Table 2 together with the results obtained by other authors. It may be pointed out that these concentrations vary from approximately 40 to $1500 \mu \mathrm{g} / \mathrm{m}^{3}$ in urban zones; from 2 to $50 \mu \mathrm{g} / \mathrm{m}^{3}$ in rural zones; from 0.2 to $9 \mu \mathrm{g} / \mathrm{m}^{3}$ in marine areas close to continents and from 0.04 to $1 \mu \mathrm{g} / \mathrm{m}^{3}$ in marine areas far from all continents.

Fig. 5 shows that over the Mediterranean Sea except between Greece and Turkey $\mathrm{SO}_{2}$ atmospheric concentrations are as low as 0.2 to 1 $\mu \mathrm{g} / \mathrm{m}^{3}$, i.e. much lower than the typical European values.

Thus, off the Italian coast, at a distance of about $200 \mathrm{~km}, \mathrm{SO}_{2}$ concentrations vary between 0.2 and $0.4 \mu \mathrm{g} / \mathrm{m}^{3}$, whereas they are of the order of 5 to $40 \mu \mathrm{g} / \mathrm{m}^{3}$ over Europe. Hence the residence time of $\mathrm{SO}_{2}$ appears to be very small over the sea, e.g. only a few hours.

Fig. 6 shows the values measured over oceanic areas in the southern hemisphere during the 1971 and 1972 expeditions. Three main regions should be distinguished after the order of magnitude of the encountered concentrations.

Table 2. $\mathrm{SO}_{2}$ atmospheric concentration

\begin{tabular}{lcl}
\hline & $\begin{array}{l}\text { Concentration } \\
\left(\mu \mathrm{g} / \mathrm{m}^{3}\right)\end{array}$ & Reference \\
\hline Location & $\sim 40-1500$ & \\
Urban & $280-1500$ & Greenburg-Jacobs (1956) \\
Few York & 40 & Neuwirth (1958) \\
England (industrial area) & $50-180$ & Meetham (1959) \\
Frankfurt/Main (Winter) & $\mathbf{4 4 3}$ & Georgii (1960) \\
Frankfurt/Main (Summer) & 87 & Georgii (1960) \\
Rural & $\sim 0.6-50$ & \\
Sweden: offer & $0-13$ & Egner-Eriksson (1955) \\
Sweden: Alnarp & $6-42$ & Egner-Eriksson (1955) \\
Florida & 3 & Junge (1956) \\
England (rural area) & 20 & Meetham (1959) \\
Zugspitze (3 000 m) & 47 & Georgii (1960) \\
St. Moritz (August) & $<10$ & Georgii (1960) \\
Panama & $<3-15$ & Lodge-Pate (1966) \\
Colorado & $0.6-2.3$ & Georgii (1970) \\
Marine & & \\
Close to continent & $\sim 0.2-9$ & \\
$\quad$ Atlantic Ocean & $<0.5-4$ & Georgii (1970) \\
Mediterranean Sea & $0.2-9$ & Present work \\
Far from all continents & $0.04-1.0$ & \\
$\quad$ Antarctic & $<1.5-5$ & Cadle et al. (1968) \\
Antarctic area & $0.05-0.5$ & Present work \\
Subantarctic area & $0.04-0.9$ & Present work \\
\hline
\end{tabular}




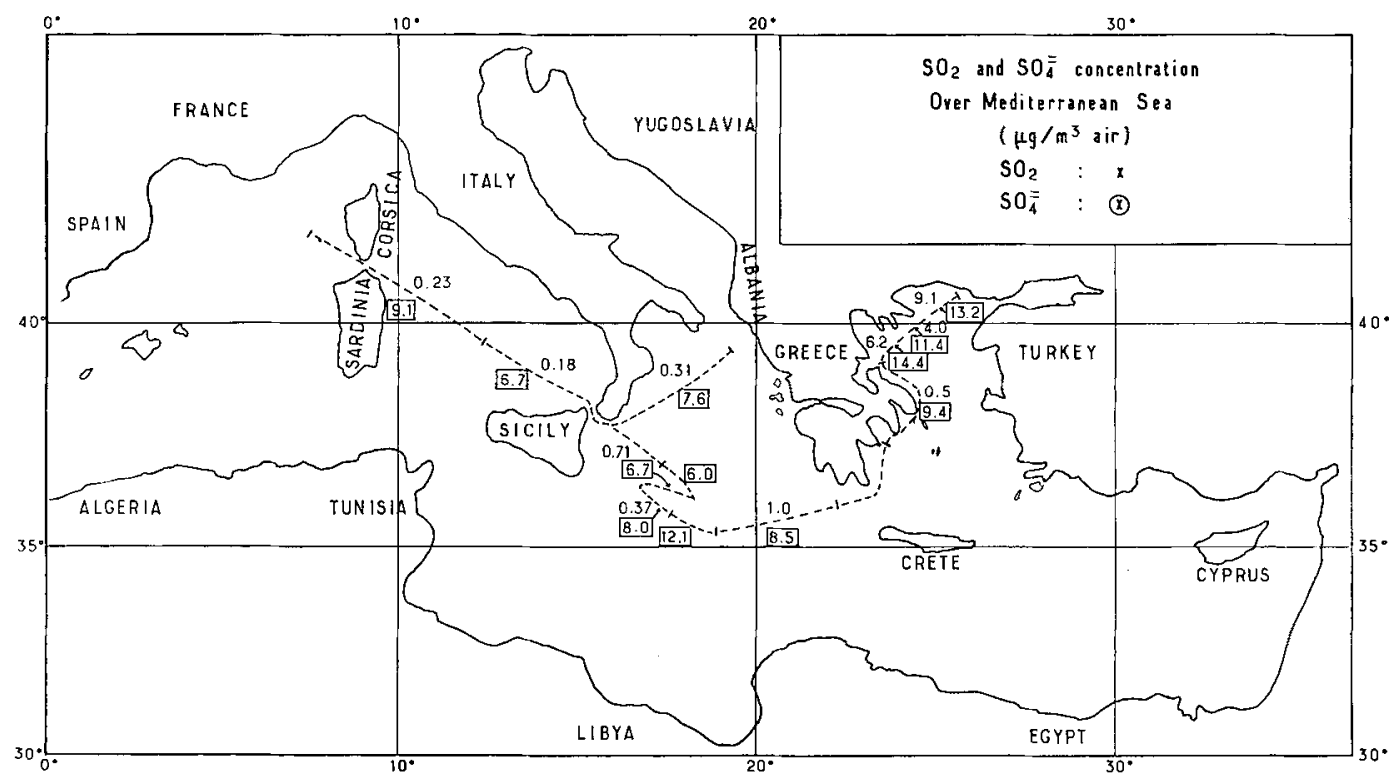

Fig. 5. $\mathrm{SO}_{2}$ and $\mathrm{SO}_{4}$ atmospheric concentrations over Mediterranean Sea

North of $30^{\circ} \mathrm{S}$, despite the proximity of Mada. gascar to the West, the concentrations come down to $0.04 \mu \mathrm{g} / \mathrm{m}^{3}$. Such low concentrations could be explained by the generally easterly wind in this area together with the position of the ship extremely far from Australia.

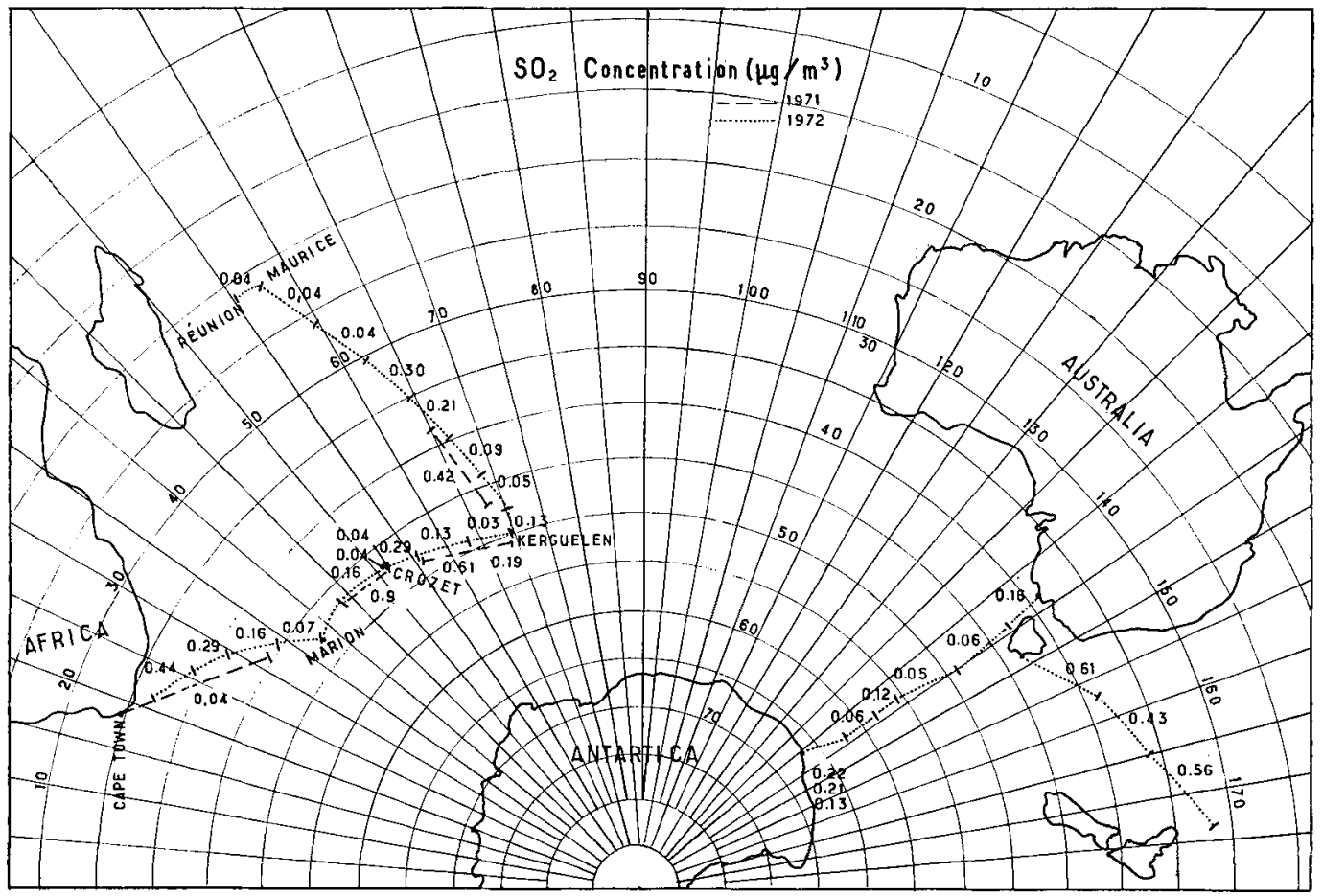

Fig. 6. $\mathrm{SO}_{2}$ atmospheric concentration over Subantarctic and Antarctic areas

Tellus XXVI (1974), 1-2 


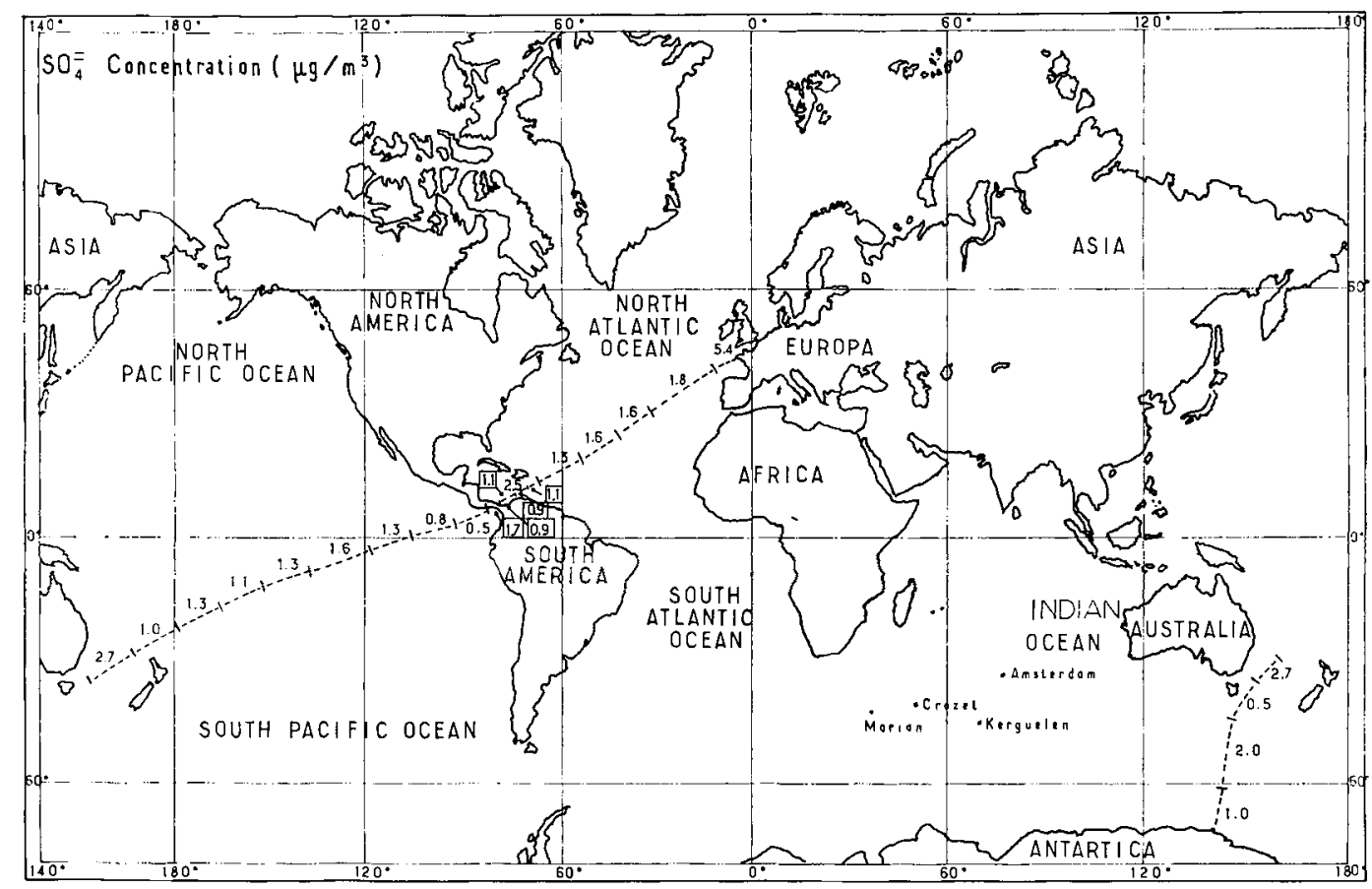

Fig. 7. Atmospheric sulfate aerosol concentration over the Atlantic and the Pacific.

South of $30^{\circ} \mathrm{S}$, the wind is mainly westerly, sometimes northwesterly: this could explain $\mathrm{SO}_{2}$ concentrations generally ranging from 0.04 to $0.9 \mu \mathrm{g} / \mathrm{m}^{3}$.

In the Tasmanian Sea, i.e. leeward of Austral. ia, the concentrations are again the same range as in the Mediterranean Sea: from 0.4 to 0.6 $\mu \mathrm{g} / \mathrm{m}^{3}$.

However, these general considerations on air mass trajectories cannot by themselves account for $\mathrm{SO}_{2}$ concentration variations over the Antarctic and Subantarctic areas.

It seems probable that, allowing for the very short residence time of $\mathrm{SO}_{2}$ over the oceans (i.e. a fow hours) remote continental influences should be practically negligible over central and southern Indian Ocean and in Antarctic regions.

There, the wide concentration range $(0.04$ to $0.9 \mu \mathrm{g} / \mathrm{m}^{3}$ ) should be accounted for only by local considerations.

It is reasonable to think that the ocean could play the part both of a source and a sink of $\mathrm{SO}_{2}$. If this is so, the variations in atmospheric concentration observed should reflect some local chemaical and biological changes of the superficial sea water and possibly of the meteorological parameters.

\section{Sulfate aerosol measurements}

During Mediterranean and Antarctic expeditions, we also made sulfate aerosol samplings.

Each sampling was carried out during 24 hours with a "Poelmann Schneider" filter. The air flow was $12 \mathrm{~m}^{3} /$ hour. As far as smoke protection is concerned the same precautions were taken as in the case of $\mathrm{SO}_{2}$ sampling.

The soluble sulfates were extracted by ultrasound cleansing from previously calcinated filters. Their concentrations were measured by the turbidimetric barium sulfate method. The background level was $25 \mu \mathrm{g}$ of sulfates which is comparable to the smallest sample collected, i.e. $72 \mu \mathrm{g}$ for a $0.3 \mu \mathrm{g} / \mathrm{m}^{3}$ atmospheric concentration.

Atmospheric sulfate aerosol concentrations over the Atlantic and the Pacific (Fig. 7) range from 2 to $5 \mu \mathrm{g} / \mathrm{m}^{3}$ close to continents and from 0.5 to $1.8 \mu \mathrm{g} / \mathrm{m}^{3}$ in the middle of oceans.

These figures are in agreement with those 
Table 3. Atmospheric concentration of sulfur dioxide and sulfate aerosols

\begin{tabular}{|c|c|c|c|}
\hline Location & $\begin{array}{l}\mathrm{SO}_{2} \\
\left(\mu \mathrm{g} / \mathrm{m}^{3}\right)\end{array}$ & $\begin{array}{l}\mathrm{SO}_{4}^{=} \\
\left(\mu \mathrm{g} / \mathrm{m}^{3}\right)\end{array}$ & $\mathrm{SO}_{2} / \mathrm{SO}_{4}^{=}$ \\
\hline Antarctic $\left(60^{\circ} \mathrm{S}-70^{\circ} \mathrm{S}\right)$ area & 0.13 & 1.57 & 0.08 \\
\hline Subantarctic $\left(40^{\circ} \mathrm{S}-60^{\circ} \mathrm{S}\right)$ area & 0.18 & 1.68 & 0.11 \\
\hline South Pacific Ocean $\left(20^{\circ} \mathrm{S}-40^{\circ} \mathrm{S}\right)$ & 0.12 & 1.15 & 0.10 \\
\hline North Atlantic Ocean $\left(50^{\circ} \mathrm{N}-8^{\circ} \mathrm{N}\right)$ & & 2.33 & \\
\hline Mediterranean Sea & 2.27 & 8.43 & 0.27 \\
\hline $\begin{array}{l}\text { Boulder; Colorado } \\
\text { Ground } \\
5.2 \mathrm{~km} \text { (above ground) }\end{array}$ & $\begin{array}{l}2.1 \\
0.4\end{array}$ & $\begin{array}{l}1.7 \\
0.1\end{array}$ & $\begin{array}{l}1.3 \\
4.0\end{array}$ \\
\hline $\begin{array}{l}\text { Germany } \\
\quad \text { Ground to } 1600 \mathrm{~m} \\
\quad \text { (unpolluted area) at } \simeq 2800 \mathrm{~m}^{a}\end{array}$ & $\begin{array}{l}\left(\mu \mathrm{g} / \mathrm{Nm}^{3}\right) \\
4-25 \\
\sim 1\end{array}$ & $\begin{array}{l}\left(\mu \mathrm{g} / \mathrm{Nm}^{3}\right) \\
3-7 \\
\sim 4\end{array}$ & $\begin{array}{l}5-3 \\
0.25\end{array}$ \\
\hline Sweden & $\mathrm{SO}_{2}-\mathrm{S}$ & $\mathrm{SO}_{4}^{=}-\mathrm{S}$ & $\mathrm{SO}_{2}-\mathrm{S} / \mathrm{SO}_{4}^{-}-\mathrm{S}$ \\
\hline 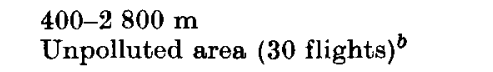 & $\quad(\mu \mathrm{g}$ & $0.1-1.6$ & $10-4$ \\
\hline
\end{tabular}

${ }^{a}$ Georgii (1970). ${ }^{b}$ Rodhe (1972).

found by Junge (1969) and Georgii (1970) in similar places.

Over the Mediterranean the concentrations are shown in frames in Fig. 5. These high concentrations (from 6 to $13 \mu \mathrm{g} / \mathrm{m}^{3}$ ) are very close to the concentrations of 3 to $10 \mu \mathrm{g} / \mathrm{m}^{3}$ observed in Germany by Georgii (1970) below $2.8 \mathrm{~km}$ altitude. Such high values of sulfate aerosol concentrations prove that over the Mediterranean most of these aerosols come from Europe. This origin is confirmed by the radon measurements over the Mediterranean Sea where the concentration of this nuclide is intermediate between continental and oceanic figures (Nguyen Ba Cuong, 1968). Moreover the lifetime of sulfate aerosols in the lower atmosphere is certainly long enough ( 2 or 3 days) to let them reach the Mediterranean Sea (Lambert et al., 1972).

\section{Comparison of $\mathrm{SO}_{2}$ and $\mathrm{SO}_{4}^{=}$ concentrations}

Table 3 indicates the average concentrations of $\mathrm{SO}_{2}, \mathrm{SO}_{4}^{-}$and their ratio for regions investigated in the present work and in papers by Georgii (1970), and Rhode (1972). This table shows that in Antarctic, Subantarctic and Central Pacific areas in the absence of anthropogenic sulfur compounds, the ratio $\mathrm{SO}_{2} / \mathrm{SO}_{4}^{-}$is about 0.1. A small anthropogenic influence increases this ratio up to 0.27 e.g. over the Mediterranean sea and at $2800 \mathrm{~m}$ altitude over Germany. Below this altitude over Europe, this ratio rises by 10 to 100 times.

\section{Conclusion}

Two main conclusions may be drawn from our preliminary marine measurements

(a) Since Antarctic and Subantarctic areas are remote from all continents where anthro. pogenic sulfur compounds are important, $\mathrm{SO}_{2}$ atmospheric concentrations of 0.04 to $0.9 \mu \mathrm{g} / \mathrm{m}^{3}$ and sulfate aerosol concentrations of 0.5 to 1.6 $\mu \mathrm{g} / \mathrm{m}^{3}$ measured in these areas could be representative of $\mathrm{SO}_{2}$ and sulfate aerosol oceanic background of the Earth's surface.

(b) Although the air concentration in sulfates and radon over the central Mediterranean Sea is characteristic of Continental inhabited areas, the $\mathrm{SO}_{2}$ concentrations have been found very low and almost comparable to Subantarctic concentrations. A situation more or less similar is also observed in the Tasmanian Sea. Several explanations could be suggested. However, we have shown in another work that $95 \%$ of $\mathrm{SO}_{2}$ is quickly absorbed by buffer solutions having the same $\mathbf{p H}$ as sea water. ${ }^{1}$ A faster disappear- 
ance of $\mathrm{SO}_{2}$ in oceanic atmosphere could mean that we have there simultaneously oxidization of $\mathrm{SO}_{2}$ and direct absorption by sea water.

It therefore seems that the oceans should act as both a source of $\mathrm{SO}_{2}$ and of sulfates (e.g. the Pacific, Indian and Antarctic oceans) and a sink (e.g. the Mediterranean and Tasmanian seas). It appears very likely that the same process of absorption by sea water also exists in the oceans so that the concentration we measured should be a result of a combination of these two effects. The variations of Oceanic $\mathrm{SO}_{2}$ concentrations indicate how the different processes are de- pendent on biochemical and meteorological conditions.

\section{Acknowledgement}

We are very grateful to the scientific organisations: Terres Australes et Antarctiques Françaises, Expéditions Polaires Françaises, Centre National pour l'Exploitation des Océans, which allowed us to undertake our experiments aboard the oceanographic ships Galliéni, Thaladan and Charcot. We thank M. L. Labeyrie for the sampling aboard the Charcot and all scientists and staff for their assistance.

\section{REFERENCES}

Cadle, R. D., Fisher, W. H., Frank, E. R. \& Lodge, J. P., Jr. 1968. Particles in the Antaretic atmosphere. J. Atmos. Sci. 25, 100-103.

Challenger, F. 1951. Biological methylation. $A d$ vances in Enzymology 12, 429-491.

Egner, H. \& Eriksson, E. 1955. Current data on the chemical composition of air and precipitation. Tellus 7, 134-139.

Eriksson, E. 1959, 1960. The yearly circulation of chloride and sulfur in nature; meteorological, geochemical and pedological implications. Tellus 11, 375-403; Tellus 12, 63-109.

Friend, J.P. 1973. The global sulfur cycle (abstracts). International Symposium on atmospheric trace gases, Mainz, April 2-6.

Georgii, H. W. 1960. Untersuchungen über atmosphärische Spurenstoffe und ihre Bedeutung für die Chemie der Niederschläge. Geolis. Pura e Appl. $47,155-171$.

Georgii, H.W. 1970. Contribution to the atmospheric sulfur budget. $J$. Geophys. Res. 75, 2365-2371.

Greenburg, L. \& Jacobs, M. B. 1956. Sulfur dioxide in New York city atmosphere. Ind. Eng. Chem. 48, 1517-1521.

Johnstone, H. F. \& Coughanowr, D. R. 1958, Absorption of sulfur dioxide from air. Ind. Engin. Chem. 50, $1169-1172$.

Junge, C. E. 1956. Recent investigation in air chemistry. Tellus 8, 127-139.

Junge, C. E., Robinson, E. \& Ludwig, A. L. 1969. A study of aerosols in Pacific air masses. $J$. Appl. Metearol. 8, 340.

Kellogg, W. W., Cadle, R. D., Allen, E. R., Lazrus, A. L. \& Martell, E. A. 1972. The sulfur cycle. Science 175, 587-596.

Lambert, G., Ardouin, B., Polian, G. \& Sanak, J. 1972. Natural radioactivity balance in the atmosphere of the Southern hemisphere. 2nd International Symposium on Natural Radiation Environment, Houston (Texas), August 7-11.

Lahmann, E. 1969. The stability of absorption solutions for sulfur dioxide determination by the West Greke method. Staub-Reinhalt. Luft. 29.
Lodge, J. P. \& Pate, J. B. 1966. Atmospheric gases and particulates in Panama. Science 153, 408-410.

Lovelock, J. E., Maggs, R. J. \& Rasmussen, R. A. 1972. Atmospheric Dimethyl Sulphide and the Natural Sulphur cycle. Nature 237, 452-453.

Meetham, A. R. 1959. The behaviour of sulphur dioxide in the atmosphere. In Atmospheric chemistry of chloride and sulphur compounds (ed. J. P. Lodge), Geophys. Monog. no. 3, pp. 115-121. Amer. Geophys. Union and Natl. Acad. Sci.

Neuwirth, R. 1958. Einige Resultate luftchemischer Untersuchungen im Zusammenhang mit der atmosphärischen Turbulenz. Meteorol. Rundschau 11, 137-141.

Nguyen Ba Cuong, 1968. Etude par les traceurs radioactifs des échanges entre les diverses zones de l'atmosphère au-dessus des continents et des océans. Thèse doctorat d'Etat, Faculté des Sciences de Paris.

Pate, J. B. et al. 1965. Nitrogen dioxide interference in the colorimetric determination of atmospheric sulfur dioxide. Analytical Chemistry 37, 942-945.

Penkett, S. A. 1972. Oxidation of $\mathrm{SO}_{2}$ and other atmospheric gases by ozone in aqueous solutions. Nature 240, 105-107.

Robinson, E. \& Robbins, R. C. 1969. Gaseous atmospheric pollutants from urban end natural sources. 6th Annual Meeting Air Pollution Control Association New York City, June 22-26.

Rhode, H. 1972. Measurements of sulfur in the free atmosphere over Sweden 1969-1970. J. Geophys. Res. 7\%, 4494-4499.

West, P. W. \& Gaeke, G. C. 1956. Fixation of sulfur dioxide as disulfitomercurate(II) and subsequent colorimetric estimation. Analytical Chem. 28, 1816-1819.

Zurlo, N. \& Griffini, G. 1962. Measurement of $\mathrm{SO}_{2}$ content of the air in the presence of oxides of nitrogen and heavy metals. La Medicina de Lazora (Milan) 53, 330-335. 


\section{АТМОСФЕРНЫЕ КОНЦЕНТРАЦИИ ДВУОКИСИ СЕРЫ И СУЛЬФАТНЫХ АЭРОЗОЛЕЙ НАД АНТАРКТИКОЙ, СУБАНТАРКТИЧЕСКИМИ ОБЛАСТЯМИ И ОКЕАНАМИ}

Во время нескольких рейсов были предприняты измерения $\mathrm{SO}_{2}$ и сульфатных аәрозолей над Антарктикой и субантарктическими областями, а также над Средичемным морем. Специальное применение Вест Гейк метода позволило измерить концентрации $\mathrm{SO}_{2} \quad$ в
Антарктике и субантарнтических областях и получить значения от 0,05 до $1 \mathrm{m \kappa 2} / \mathrm{k}^{3}$. Концентрации $\mathrm{SO}_{2}$ и сульфатных аэрозолей в. этих областях затем сравниваютея с другими концентрациями, наблюдаемыми в различных областях. 